\title{
Access to Justice for the Disability Women as Victims in the Criminal Justice System
}

\author{
Cahya Wulandari ${ }^{1 *}$, \\ ${ }^{1}$ Faculty of Law, Universitas Negeri Semarang, Semarang, Indonesia
}

\begin{abstract}
Women are the parties who have potential chance to be victims; this problem is regardless of patriarchy culture which is still very strong in the community. Women are considered vulnerable, moreover those who have dissabilities. Disability women are less able to protect themself from the violence. These problems are related to access to have the rights in justice for those disability women who become the victims of violence. This research used primary data and secondary data with qualitative research through juridical sociological approach. The violence which often occurs to women could be physical, verbal, sexual, as well as psychic violence. The disability women as victims get less access to justice and protection as set in regulations because they are lack of understanding from law enforcer about disability. Moreover, there is no infrastructure that can support the rights of disability women.
\end{abstract}

\section{Introduction and Literature Review}

Violence against women is now increasingly diverse and it happens everywhere, while the prevention and the handling are slow [1]. Violence also happens to those women with disabilities. Women with disabilities are recognized as having enormous potential both inside and outside the home, including exploitation [2]. An example is the case of rape that occurred in Wonosobo and Semarang in 2016-2017. On the other hand, women with disabilities as victims of violence are things that have not been resolved properly [3].

The form of injustice is that women with disabilities as victims get various obstacles and difficulties in giving evidence; often their evidence is questioned by the law enforcers. In addition, they also often get intimidation from various parties, ranging from criminals to law enforcers. Another thing that happens is that people with disabilities are considered incapable of law, and the absence of an adequate translator in the court process. The existing Criminal Code Procedure also does not accommodate the interests of other types of disabilities such as people with mental and intellectual disabilities, blind people, behavioral and hyperactivity disorders, bipolar disorder, mental health disorders and mentally disabled people to get translator [4]

This certainly raises attention of the society, because Indonesia expressly recognizes equality before the law. Article 3 Paragraph 2 of Law No. 39 of 1999 clearly recognizes that "every person has the right to recognition, guarantees, protection and fair legal treatment and to obtain legal certainty and equal treatment before the law". Besides that in Paragraph 3 it is clear that everyone has basic human freedom without discrimination [5].

Furthermore, Article 28 of Law No. 8 of 2016 stated that "The Government shall 
guarantee and protect the rights of Persons with Disabilities as a legal subject to the same legal actions with the other". Based on these provisions, basically persons with disabilities both as victims, witnesses and as perpetrators have the same rights. Based on these problems, it is important to analyze how access to justice for victims of women with disabilities in the legal system in Indonesia.

\subsection{The Special Need Aspects of Persons with Disabilities in Law}

In relation to the realization of equal rights and without discrimination, persons with disabilities have special needs to fulfill the same legal and human rights positions as Indonesian citizens in general, including in relation to aspects of criminal procedural law [6].

In addition, in order to provide effective access to justice for persons with disabilities, the state should improve suitable training for those who work as law enforcers, including police and prison guards to accommodate the needs of persons with disabilities and integrate with the criminal justice procedural system. The most important thing is that the law enforcers must have paradigm that persons with disabilities must be treated as people who have equal rights with other human beings who are able to claim their rights. The law enforcers should no longer see that persons with disabilities as objects of treatment and social protection [7].

There are several needs in connection with the court proceedings for person with disabilities that are different from the society in general that is related to physical accessibility and accessibility in procedural [8]. Physical accessibility related to the obligation of the judiciary to ensure that physical facilities such as court buildings, courtrooms, audit proceedings, indictments and claims, accession of bells for persons with disabilities are accessible.

\subsection{Some Problems with Victims of Women with Disabilities in the Legal Process}

The problem of women with disabilities as victims in accessing justice is not only a national problem, but also a problem in several countries. In some countries, women with disabilities have obstacles in access to justice. Women are raised with feelings of inferiority that they are unable to make any demands. In addition, the results of research show that people with disabilities are often considered less credible and reliable by those in power. In addition, law enforcement often blames the victims, is lack of procedures, and there is no support of information and knowledge that can be accessed by victims [9].

In addition, related to women with disabilities, Barbara Faye Waxman Fiduccia in her research as quoted in Rosemarie stated that [10]:

Disabled women and girls are of all ages, all racial, ethnic, religious, and socioeconomic backgrounds and sexual orientations; they live in rural, urban and suburban communities. Disabled women and girls live at the corner of disability and womanhood-with two 'minority' identities, a double dose of discrimination and stereotyping and multiple barriers to achieving their life goals. While many women with disabilities derive enormous strength, resilience and creativity from their multiple identities, they also face the consequences of discrimination. Yet, the selfdefined needs of women with disabilities remain on the margins of the social justice movements that should represent them-the women's movement, the disability rights movement, and the civil rights movement-leaving disabled women and girls of all backgrounds essentially invisible.

This certainly puts women with disabilities into unfair conditions. Besides, the criminal 
justice system for women with disabilities as victims often encounter several problems including [11]: First, in a criminal case, a deaf person who becomes a victim of rape is often cornered by questions of law enforcers. The second, the reports of a person with a disability is often not processed by law enforcers.

The third, a deaf person whose case is processed in court, the investigator is often not involved in the question and answer process, and gives up completely to the translator. The fourth, law enforcers often demean the dignity of persons with disabilities. The ability and legal skills are often disputed so that there should be new knowledge for law enforcers. Persons with disabilities are individuals who have different abilities and ways of explaining things.

In addition to these problems, there is still a lack of understanding and knowledge of law enforcers who have not considered the needs of persons with disabilities to be inseparable. When dealing with cases of persons with disabilities dealing with the law, law enforcers are more likely to be positivistic. Law enforcers always refer to rules that are discriminatory. In addition, there is an unpreparedness from law enforcers in handling cases affecting people with disabilities. This is resulting from law enforcement does not have special skills to process the case of women with disabilities and persons with disabilities [12].

\section{Objective of the Study}

This study aims at analyzing access to justice for women with disabilities who become victims. This research is also inseparable from the analysis of the problems of persons with disabilities in the legal process and their causes. In addition, it is also supported by an analysis of several regulations and conventions on disability to conduct a comprehensive analysis in this study.

\section{Methodology}

In this study the method used is a normative legal research method that refers to legal norms contained in the legislation [13]. Through this normative legal research, researchers conduct an analysis of the application of regulations and cases. While the data collection used by researchers is the study of documents or library material as the main data source. After the researchers obtained data from document studies, the data was analyzed by researchers using qualitative analysis by producing descriptive-analytical data that is expressed both in writing and verbally [14].

\section{Discussion}

The state must strive to protect human rights. Handling cases involving persons with disabilities must also be subject to the protection. This applies when the person with a disability in his position as a defendant or victim, witness, or party to a civil case. The human rights of persons with disabilities in these positions must still be protected. This is based on judicial principles fair, as stipulated in Article 14 of the International Covenant concerning Civil and Political Rights, and has been ratified by Law No. 12 of 2005. Fair justice principles will be explained by referring to Manfred Nowak's about the explanation of Article 14 International Covenant on Civil and Political Rights.

In fact, the legal norms still treat the disabilities person as a people who can not afford, not normal, under legal guardianship and incompetent. Automatically, people with disabilities seem to be victims of the judicial process [15]. Substance, culture, and legal structure are things that can not be separated from this problem. In addition, some of the 
problems mentioned above can not also be separated from the references used by law enforcers in carrying out legal proceedings against persons with disabilities who are still using the Criminal Procedure Code. The provisions that apply to persons with disabilities also use the Criminal Procedure Code, though they have special needs and limitations which are certainly different from normal society.

In addition, Indonesia has ratified the Convention on the Rights of Persons with Disabilities [16]. In this provision recognized that women with disabilities should be guaranteed and equal in terms of freedom and human rights [17]. In addition, the state must also take appropriate steps to make physical, cognitive and psychological recovery for women with disabilities who are victims [18]. Based on this, the country certainly has an obligation to provide protection to women with disabilities who are victims, including the injustice of the legal process.

In addition to the aspect of law enforcement, persons with disabilities are also entitled to a fair trial process, as mandated by Article 14 of the International Covenant on Civil and Political Rights. This article contains procedural guarantees so that the trial runs well and fairly. Some of the specificities that must be considered in the judicial process for persons with disabilities are the need for the availability of different court services from the average person. This becomes a necessity that cannot be inevitable so that the government has an obligation to realize justice that can be proper for people with disabilities.

The other thing that became the basis for the rights of women with disabilities who become victims are General Recommendation of CEDAW [19] which states that the state must:

Develop effective and independent mechanisms to observe and monitor women's access to justice in order to ensure that justice systems are in accordance with the principles of justice, availability, accessibility, good quality and effectiveness of remedies. This includes the periodical audit/review of the autonomy, efficiency and transparency of the judicial, quasi-judicial and administrative bodies taking decisions affecting women's rights

Based on this, the state has an obligation to ensure access to justice for women including persons with disabilities based on principles that are fair and easy to access and have good quality. Several ways can be done to realize these ideals, one of which is through freedom of resolution of cases based on the willingness of the victim. This aims to realize the process of resolving cases in accordance with the wishes of victims who are considered able to provide justice.

Basically the problem of women with disabilities as victims of not only happen in Indonesia, but to be a problem in some countries that a meeting to discuss the issue. The country is like Austria, Germany, Iceland and England. In these countries women with disabilities are recognized more often abused than normal women in general. Women with disabilities in finding injustice and faced many obstacles [20].

This was overcome by Austria by adopting an NAP which contained support and counseling for women with disabilities who were victims of crime. In Germany to overcome this problem a national action plan was formed in 2007 and formed a government working group. In general, the four countries have a supporting structure to overcome these problems [21].

Based on this, Indonesia as a country that upholds respect for human rights should provide protection to women with disabilities who are victims of crime. It aims to provide access to justice that is appropriate to the needs of persons with disabilities. In addition, the assessment of facilities and infrastructure in undergoing the legal process also becomes equally important to be considered together. 


\section{Conclusion}

Women with disabilities who are victims of crime experience injustice in undergoing legal proceedings, including as victims experience various obstacles and difficulties in giving evidence, often their evidence are questioned by law enforcers. In addition they also often get intimidation from various parties ranging from criminals to law enforcers. This is inseparable from the influence of substance, culture and legal structure. Indonesia as a country that upholds human rights and has ratified conventions relating to persons with disabilities has a moral obligation to provide equal access to justice for persons with disabilities. This can be done by providing a choice to resolve cases that are fully handed over to victims and form regulations that can facilitate victims to access justice. It aims at solving the problems that have occurred for the process of obtaining justice.

\section{References}

1. Annual Notes on Violence against Women (National Commission on Violence against Women, Jakarta, 2018).

2. See the Preambule of the Convention on the Rights of Persons with Disabilities Point (q).

3. B. R. Muqoddas, Perlindungan Hukum Bagi Perempuan Penyandang Disabilitas Sebagai Korban Kekerasan Dalam Perspektif Hukum Hak Asasi Manusia di Daerah Istimewa Yogyakarta, (Faculty of Law, Indonesian Islamic University, 2018).

4. E. Wahyudi, "Perempuan Disabilitas Sulit Dapatkan Keadilan dalam Hukum" accessed at : https://www.cnnindonesia.com/nasional/20150630211545-20-63439/ perempuandisabilitas-sulit-dukup-keadilan-dalam-hukum (2015).

5. This article is then outlined in the context of persons with disabilities in Law No. 8 of 2016. Article 3 letters (a) explain that respect, promotion, protection and fulfillment of human rights and basic freedoms of persons with disabilities are fully and equally recognized.

6. S. W. Eddyono, Aspek-aspek Criminal Justice bagi Penyandang Disabilitas, (Institute for Criminal Justice Reform, Jakarta, 2015).

7. S. W. Eddyono, Aspek-aspek Criminal Justice bagi Penyandang Disabilitas, (Institute for Criminal Justice Reform, Jakarta, 2015).

8. S. Marzuki in Foreword for the book "Aksesibilitas Peradilan Bagi Penyandang Disabilitas", (Center for the Study of Human Rights Indonesian Islamic University, Yogyakarta, 2015).

9. S. Mandl, et.al, Access to Specialised Victim Support Services for Women with Disabilities who have Experienced Violence, (Ludwig Boltzmann Institute of Human Rights, 2014).

10. Double Oppression; Violence against Disabled Women: A Resource Pack for Practical Access, accessed at http://www.niaendingviolence.org.uk/perch/resources/ doubleoppression-violence-against-disabled-women.pdf

11. Syafi'ie, Purwanti and M. Ali, Potret Difabel Berhadapan dengan Hukum Negara, (SIGAB, Yogyakarta, 2014).

12. B. R. Muqoddas, Perlindungan Hukum Bagi Perempuan Penyandang Disabilitas Sebagai Korban Kekerasan Dalam Perspektif Hukum Hak Asasi Manusia di Daerah Istimewa Yogyakarta, (Faculty of Law, Indonesian Islamic University, 2018).

13. S. Soekanto and S. Mamudji, Penelitian Hukum Normatif, (Raja Grafindo Persada, Jakarta, 2004).

14. S. Soekanto and S. Mamudji, Penelitian Hukum Normatif, (Raja Grafindo Persada, Jakarta, 2004).

15. PUSHAM, Aksesibilitas Peradilan Bagi Penyandang Disabilitas, Yogyakarta (Center for 
the Study of Human Rights Indonesian Islamic University, Yogyakarta, 2015).

16. The ratification was carried out through Law Number 19 of 2011 on the Ratification of the Convention on the Rights of Persons with Disabilities.

17. See Article 6 of the Convention on the Rights of Persons with Disabilities

18. See Article 16 of the Convention on the Rights of Persons with Disabilities

19. See Article 20 points (a), General recommendation on women 's access to justice from the Committee on the Elimination of Discrimination against Women (2015)

20.S. Mandl, et.al, Access to Specialised Victim Support Services for Women with Disabilities who have Experienced Violence, (Ludwig Boltzmann Institute of Human Rights, 2014).

21.S. Mandl, et.al, Access to Specialised Victim Support Services for Women with Disabilities who have Experienced Violence, (Ludwig Boltzmann Institute of Human Rights, 2014). 